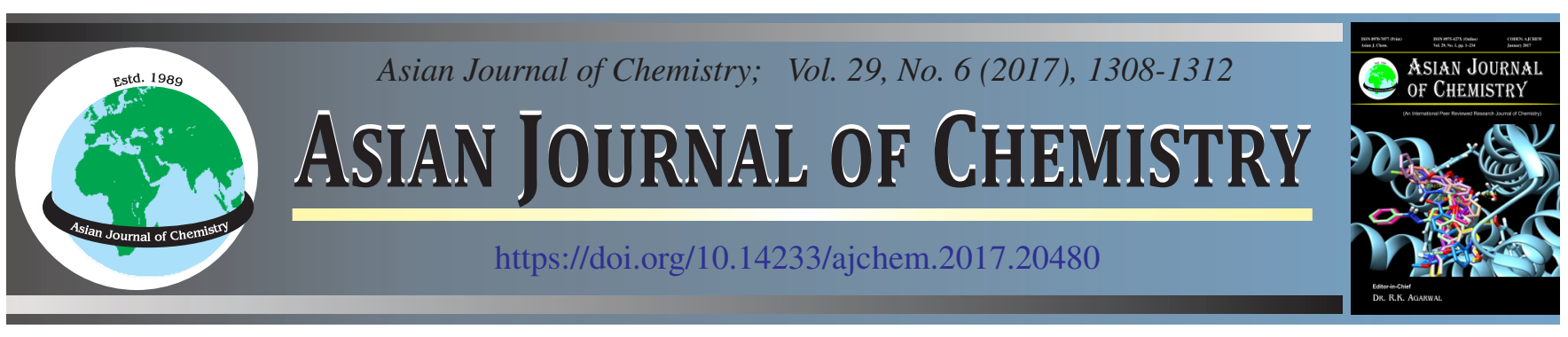

\title{
Synthesis, Characterization and Antibacterial Studies of VO(IV), Cu(II), Ni(II), Co(II) Chelates of Tetradentate Schiff Base Derived from Benzil and Anthranilic Acid
}

\author{
N. Gayathri and M.S. Suresh ${ }^{*}$
}

Department of Chemistry, Government Arts College, Udhagamandalam-643002, India

*Corresponding author: E-mail: mssgacooty@gmail.com; sanjeevigk@gmail.com

\begin{abstract}
A novel tetradentate $\mathrm{N}_{2} \mathrm{O}_{2}$ type Schiff base, synthesized from benzil and 2-aminobenzoic acid (anthranilic acid) in the ratio 1:2, form stable complexes with transition metal ions such as $\mathrm{VO}$ (IV), $\mathrm{Cu}$ (II), $\mathrm{Ni}$ (II) and $\mathrm{Co}$ (II) in ethanol. Microanalytical data, magnetic susceptibility, molar conductance measurements, FTIR, UV-visible, ESR spectroscopic techniques and thermal analysis were used to confirm their structures. These complexes show very low conductance values supporting non-electrolytic nature. The infrared spectra supports the involvement of azomethine nitrogens and oxygen from carboxylate ion are coordinated to the metal. Electronic spectra of the complexes suggest a square pyramidal geometry for oxovanadium(IV) complex [VO(L)], distorted octahedral geometry for $\mathrm{Cu}$ (II) and $\mathrm{Co}$ (II)complexes and octahedral geometry for $\mathrm{Ni}(\mathrm{II})$ complexes with general formula $\left[\mathrm{M}(\mathrm{L})\left(\mathrm{H}_{2} \mathrm{O}\right)_{2}\right]$ where $\mathrm{M}=\mathrm{Cu}(\mathrm{II}), \mathrm{Ni}$ (II), $\mathrm{Co}$ (II). The X-band ESR spectra of $\mathrm{VO}(\mathrm{IV})$ and $\mathrm{Cu}$ (II) complexes were recorded in DMSO at LNT and their parameters were calculated. All these complexes are paramagnetic and thermal studies show that in all the cases a stable metal oxide was obtained as the residue. The metal complexes have been screened for their antibacterial activity against organisms like E. coli, S. aureus, Serattai sp, P. aeruginosa and B. cereus and it was found that the complexes were more active than the corresponding ligand.
\end{abstract}

Keywords: Schiff base, Benzil, Anthranilic acid, Metal complexes, Antibacterial studies.

\section{INTRODUCTION}

Addition of an amine to a compound containing a carbonyl functional group produces an imine $(\mathrm{N}=\mathrm{CH}-)$ known as Schiff bases. Schiff bases have been playing an important part in the development of coordination chemistry. Schiff base metal complexes have been studied extensively because of their attractive chemical and physical properties and their wide range of applications in numerous scientific areas. They play an important role in both synthetic and structural research, because of their preparative accessibility and structural diversity [1]. These complexes are extensively examined due to their wide applications in various fields like biological, pharmacological, clinical, analytical [2-4] and industrial area [5]. A search through the literature reveals that no work has been done on transition metal complexes of Schiff bases formed by the condensation of benzil and anthranilic acid. So in this paper we describe the synthesis, structural characterization and antibacterial studies of Schiff base complexes derived from benzil and anthranilic acid $\left[\mathrm{N}_{2} \mathrm{O}_{2}\right.$ donor].

\section{EXPERIMENTAL}

Benzil, anthranilic acid, $\operatorname{VOSO}_{4} \cdot 5 \mathrm{H}_{2} \mathrm{O}, \mathrm{CuCl}_{2} \cdot 2 \mathrm{H}_{2} \mathrm{O}$, $\mathrm{NiCl}_{2} \cdot 5 \mathrm{H}_{2} \mathrm{O}, \mathrm{CoCl}_{2} \cdot 6 \mathrm{H}_{2} \mathrm{O}$, ethyl alcohol, etc. were purchased from Merck and used as such without any further purification. The elemental analysis (CHNS) were performed using EL elemental analyser at Central Electrochemical Research Institute (CECRI). The FT infrared spectra were recorded in the range $4000-400 \mathrm{~cm}^{-1}$ on a Schimadzu FTIR $8400 \mathrm{~S}$ spectrometer using $\mathrm{KBr}$ pellet techniques. Electronic (UV-VIS) spectra were recorded on a Schimadzu UVspectrophototmeter in the range $200-1100 \mathrm{~cm}^{-1}$ using DMSO solvent. The thermal analyses were carried out using universal V4.5A Thermal analysis instrument in an atmosphere of static air with a heating rate of $10 \mathrm{~K} / \mathrm{min}$. The ESR spectra of various Schiff base complexes were recorded on a JES-X3 series in the scan range of 23004300 Gauss at LNT. The magnetic susceptibility measurements of the complexes were carried out using Gouy balance. The molar conductance was measured on ELICO-CM180 using DMSO as the solvent at room temperature. The antibacterial studies was carried out with disc diffusion method.

Synthesis of Schiff base of benzil and anthranilic acid (BEA): To the ethanolic solution of benzil (4.20 g, $0.02 \mathrm{~mol}$ in $20 \mathrm{~mL}$ ethanol) an ethanolic solution of 2-anthranilic acid (5.48 $\mathrm{g}, 0.04 \mathrm{~mol}$ in $20 \mathrm{~mL}$ ethanol) was added, followed by the addition of anhydrous sodium acetate ( $3 \mathrm{~g}$ ) and the mixture was refluxed for $1 \mathrm{~h}$. The hot solution was poured into ice 
cold water where upon a grey precipitate of the Schiff base was separated, filtered, washed with water, and dried in vacuo [6]. The scheme of preparation is shown in Fig. 1.

\section{Synthesis of metal complexes}

- The vanadium complex was prepared by refluxing 1:1 molar ethanolic mixture of the vanadium salt, $\mathrm{VOSO}_{4} \cdot 5 \mathrm{H}_{2} \mathrm{O}$ $(2.530 \mathrm{~g}, 0.01 \mathrm{~mol})$ with the ligand $(4.484 \mathrm{~g}, 0.01 \mathrm{~mol})$ for $3 \mathrm{~h}$ followed by dropwise addition of ammonia until metal chelate separated. It was suction filtered washed with ethanol and ether before dried in vacumm dessicator. The compound was recrystallized from rectified spirit and dried.

- The same method was adopted for other complexes in which $\mathrm{CuCl}_{2} \cdot 2 \mathrm{H}_{2} \mathrm{O}(1.704 \mathrm{~g}, 0.01 \mathrm{~mol}), \mathrm{NiCl}_{2} \cdot 5 \mathrm{H}_{2} \mathrm{O}(2.376$, $0.01 \mathrm{~mol}), \mathrm{CoCl}_{2} \cdot 6 \mathrm{H}_{2} \mathrm{O}(2.379 \mathrm{~g}, 0.01 \mathrm{~mol})$, was added to the ligand (4.484 g, $0.01 \mathrm{~mol}$ ) in ethanol medium.

\section{RESULTS AND DISCUSSION}

Elemental analysis and molar conductance studies: The analytical data (Table-1) suggests 1:1 metal:ligand stoichiometry and the synthesized complexes have the molecular formula $[\mathrm{VO}(\mathrm{BEA})]$ and $\left[\mathrm{M}(\mathrm{BEA}) \cdot\left(\mathrm{H}_{2} \mathrm{O}\right)_{2}\right]$ where $\mathrm{M}=\mathrm{Cu}^{2+}$, $\mathrm{Ni}^{2+}$ and $\mathrm{Co}^{2+}$. These complexes are stable and green in colour. These complexes have molar conductance in the range of 12.5$17.5 \mathrm{~S} \mathrm{~cm}^{2} \mathrm{~mol}^{-1}$ indicating that they are non-electrolytic in nature. The microanalytical data and its molar conductance are presented in Table-1.

Infrared analyses: IR spectra provide valuable information regarding the nature of functional group attached to the metal ion. Coordination to the metal through the nitrogen atom is expected to reduce the bond strength of azomethine group and lowers the $v(C=N)$. The spectrum of the free Schiff base ligand $\mathrm{BEA}$ shows $-\mathrm{C}=\mathrm{N}$ bands at region $1658 \mathrm{~cm}^{-1}$ shifted to lower frequency in the complexes $1615-1606 \mathrm{~cm}^{-1}$ showing the involvement of the coordination of $\mathrm{C}=\mathrm{N}$ to the metal [7-10]. The frequency corresponding to $v(\mathrm{COO})^{-}$present in the ligand $1480 \mathrm{~cm}^{-1}$ is shifted to lower values $1470-1450 \mathrm{~cm}^{-1}$ in the complexes, indicating the coordination through the oxygen atom of the carboxylate $\mathrm{COO}^{-}$anion. The $\mathrm{v}(\mathrm{OH})$ due to water is present in the range $3845-3308 \mathrm{~cm}^{-1}$ except vanadyl complex indicating the presence of hydrated water $[11,12]$. It was further supported by M-N peak at $483-426 \mathrm{~cm}^{-1}$ and $\mathrm{M}-\mathrm{O}$ peak in the range $592-585 \mathrm{~cm}^{-1}[13,14]$. A new peak at $998 \mathrm{~cm}^{-1}$ in vanadyl complex is due to $v(\mathrm{~V}=\mathrm{O})$ [15]. The IR spectral data are given in Table-2.

UV-visible electronic spectra and magnetic susceptibility measurement: The free ligand shows absorption maxima appearing around 38461 and $31250 \mathrm{~cm}^{-1}$ due to $\mathrm{n} \rightarrow \pi^{*}$ and $\pi \rightarrow \pi^{*}$ transition respectively. The electronic spectrum of [VO(BEA)] shows peaks at 11792, 15337 and $21276 \mathrm{~cm}^{-1}$ assigned to be ${ }^{2} \mathrm{~B}_{2} \rightarrow{ }^{2} \mathrm{E},{ }^{2} \mathrm{~B}_{2} \rightarrow{ }^{2} \mathrm{~B}_{1}$ and ${ }^{2} \mathrm{~B}_{2} \rightarrow{ }^{2} \mathrm{~A}_{1}$ transitions respectively supports the square pyramidal structure of the complex [16-20] and confirmed by its magnetic moment of $1.78 \mathrm{BM}$ [19]. The three peaks obtained at 10869, 16666 and $19011 \mathrm{~cm}^{-1}$ in $\mathrm{Co}(\mathrm{II})$ complexes is assigned to ${ }^{4} \mathrm{~T}_{\mathrm{lg}}(\mathrm{F}) \rightarrow$ ${ }^{4} \mathrm{~T}_{2 \mathrm{~g}}(\mathrm{~F}) \mathrm{v}_{1},{ }^{4} \mathrm{~T}_{1 \mathrm{~g}}(\mathrm{~F}) \rightarrow{ }^{4} \mathrm{~A}_{2 \mathrm{~g}}(\mathrm{~F}) \mathrm{v}_{2}$ and ${ }^{4} \mathrm{~T}_{1 \mathrm{~g}}(\mathrm{~F}) \rightarrow{ }^{4} \mathrm{~T}_{1 \mathrm{~g}}(\mathrm{P}) \mathrm{v}_{3}$, respectively suggesting a distorted octahedral geometry [17] around $\mathrm{Co}$ (II) ion. It was also supported by its magnetic moment<smiles>Nc1cc[14c]cc1</smiles><smiles>O=C(O)c1ccccc1N=C(c1ccccc1)c1ccccc1</smiles>

Fig. 1. Schematic representation of the synthesis of tetradentate ligand BEA

\begin{tabular}{|c|c|c|c|c|c|c|c|c|}
\hline \multirow{3}{*}{ Compound } & \multicolumn{7}{|c|}{$\begin{array}{r}\text { TABLE-1 } \\
\text { PHYSICAL CHARACTERISATION, ANALYTICAL }\end{array}$} & \multirow{3}{*}{$\begin{array}{c}\Lambda_{\mathrm{M}}(\mathrm{S} \mathrm{cm} \\
\left.\mathrm{mol}^{-1}\right)\end{array}$} \\
\hline & \multirow{2}{*}{ m.w. } & \multirow{2}{*}{ Colour } & \multirow{2}{*}{$\begin{array}{l}\text { Yield } \\
(\%)\end{array}$} & \multicolumn{4}{|c|}{ Elemental analysis (\%): Found (calcd.) } & \\
\hline & & & & $\mathrm{C}$ & $\mathrm{H}$ & $\mathrm{N}$ & M & \\
\hline $\mathrm{C}_{28} \mathrm{H}_{20} \mathrm{~N}_{2} \mathrm{O}_{4}(\mathrm{BEA})$ & 448.46 & Grey & 80 & $72.79(74.98)$ & $4.221(4.495)$ & $6.013(6.248)$ & - & - \\
\hline$[\mathrm{VO}(\mathrm{BEA})]$ & 515.4 & Dark green & 75 & $65.24(65.24)$ & $3.9115(3.9115)$ & $5.411(5.436)$ & $12.90(12.98)$ & 13.5 \\
\hline$\left[\mathrm{Cu}(\mathrm{BEA}) \cdot\left(\mathrm{H}_{2} \mathrm{O}\right)_{2}\right]$ & 548.04 & Green & 75 & $60.55(61.36)$ & $4.257(4.414)$ & $5.100(5.112)$ & $11.00(11.59)$ & 13.5 \\
\hline$\left[\mathrm{Ni}(\mathrm{BEA}) \cdot\left(\mathrm{H}_{2} \mathrm{O}\right)_{2}\right]$ & 543.20 & Green & 70 & $60.55(61.92)$ & $4.257(4.453)$ & $5.100(5.158)$ & $11.00(10.80)$ & 17.5 \\
\hline$\left[\mathrm{Co}(\mathrm{BEA}) \cdot\left(\mathrm{H}_{2} \mathrm{O}\right)_{2}\right]$ & 543.42 & Green & 70 & $60.90(61.88)$ & $4.233(4.451)$ & $4.989(5.156)$ & $11.10(10.80)$ & 12.5 \\
\hline
\end{tabular}

TABLE-2

INFRARED SPECTRAL DATA OF THE SCHIFF BASES AND ITS METAL COMPLEXES

\begin{tabular}{lcccccc}
\multicolumn{1}{c}{ Compound } & $v(\mathrm{OH})$ & $v(\mathrm{C}=\mathrm{N})$ & $v(\mathrm{COO})^{-}$ & $v(\mathrm{M}-\mathrm{O})$ & $v(\mathrm{M}-\mathrm{N})$ & $v(\mathrm{~V}=\mathrm{O})$ \\
\hline $\mathrm{C}_{28} \mathrm{H}_{20} \mathrm{~N}_{2} \mathrm{O}_{4}(\mathrm{BEA})$ & - & 1658 & 1480 & - & - & - \\
{$[\mathrm{VO}(\mathrm{BEA})]$} & - & 1615 & 1450 & 590 & 467 & 998 \\
{$\left[\mathrm{Cu}(\mathrm{BEA}) \cdot\left(\mathrm{H}_{2} \mathrm{O}\right)_{2}\right]$} & 3345 & 1606 & 1459 & 590 & 483 & - \\
{$\left[\mathrm{Ni}(\mathrm{BEA}) \cdot\left(\mathrm{H}_{2} \mathrm{O}\right)_{2}\right]$} & 3305 & 1614 & 1457 & 592 & 450 & - \\
{$\left[\mathrm{Co}(\mathrm{BEA}) \cdot\left(\mathrm{H}_{2} \mathrm{O}\right)_{2}\right]$} & 3308 & 1613 & 1457 & 585 & 426 & - \\
\hline
\end{tabular}


value of $4.40 \mathrm{BM}$ [21]. The electronic spectrum of $\mathrm{Cu}(\mathrm{II})$ complex shows $d$ - $d$ transition band in the range 13037, 19083 and $24038 \mathrm{~cm}^{-1}$ corresponds to ${ }^{2} \mathrm{~A}_{1 \mathrm{~g}} \rightarrow{ }^{2} \mathrm{~B}_{1 \mathrm{~g}}\left(\mathrm{dz}^{2} \rightarrow \mathrm{dx}^{2}-\mathrm{y}^{2}\right) \mathrm{v}_{1}$, ${ }^{2} B_{2 g} \rightarrow{ }^{2} B_{1 g}\left(d_{x y} \rightarrow d_{x^{2}-y^{2}}\right) v_{2}$ and ${ }^{2} E_{g} \rightarrow{ }^{2} B_{1 g}\left(d_{x z}, d_{y z} \rightarrow d_{x^{2}-y^{2}}\right) v_{3}$ transition respectively [17]. The spectrum is typical for a distorted octahedral geometry. The magnetic moment of 1.86 $\mathrm{BM}$, also supports this [21]. The electronic spectrum of $\mathrm{Ni}(\mathrm{II})$ complex shows three absorption maxima at 12315, 14450 and $20283 \mathrm{~cm}^{-1}$. These are characteristic of octahedral Ni(II) complexes and assigned to be ${ }^{3} \mathrm{~A}_{2 \mathrm{~g}} \rightarrow{ }^{3} \mathrm{~T}_{2 \mathrm{~g}}(\mathrm{~F}) \mathrm{V}_{1},{ }^{3} \mathrm{~A}_{2 \mathrm{~g}} \rightarrow{ }^{3} \mathrm{~T}_{1 \mathrm{~g}}(\mathrm{~F}) \mathrm{V}_{2}$ and ${ }^{3} \mathrm{~A}_{2 \mathrm{~g}} \rightarrow{ }^{3} \mathrm{~T}_{1 \mathrm{~g}}(\mathrm{P}) \rightarrow \rightarrow_{3}$ transition respectively [22]. Its magnetic moment was found to be $3.01 \mathrm{BM}$ supporting octahedral environment [21] around $\mathrm{Ni}(\mathrm{II})$ ion (Table-3).

\begin{tabular}{|c|c|c|c|}
\hline $\begin{array}{r}\text { UV } \\
\text { MAGNE }\end{array}$ & $\begin{array}{r}\text { TABI } \\
\text { IBLE SPEC } \\
\text { MOMENTS }\end{array}$ & $\begin{array}{l}\text { L DATA AND } \\
\text { THE COMPLEXE }\end{array}$ & \\
\hline Compound & $\begin{array}{l}\text { Absorption } \\
\max \left(\mathrm{cm}^{-1}\right)\end{array}$ & Assignments & $\begin{array}{c}\mu_{\text {eff }} \\
(\mathrm{BM})\end{array}$ \\
\hline $\mathrm{C}_{2} \mathrm{H}_{2} \mathrm{~N}_{2} \mathrm{O}(\mathrm{BEA})$ & 38461 & $\mathrm{n} \rightarrow \pi^{*}$ & \\
\hline $\mathrm{C}_{28} \mathrm{H}_{20} \mathrm{~N}_{2} \mathrm{O}_{4}$ (BEA) & 31250 & $\pi \rightarrow \pi^{*}$ & \\
\hline & 11792 & ${ }^{2} \mathrm{~B}_{2} \rightarrow{ }^{2} \mathrm{E}$ & \\
\hline [VO(BEA)] & 15337 & ${ }^{2} \mathrm{~B}_{2} \rightarrow{ }^{2} \mathrm{~B}_{1}$ & 1.78 \\
\hline & 21276 & ${ }^{2} \mathrm{~B}_{2} \rightarrow{ }^{2} \mathrm{~A}_{1}$ & \\
\hline & 13037 & ${ }^{2} \mathrm{~A}_{1 \mathrm{~g}} \rightarrow{ }^{2} \mathrm{~B}_{1 \mathrm{~g}}\left(\mathrm{v}_{1}\right)$ & \\
\hline$\left[\mathrm{Cu}(\mathrm{BEA}) \cdot\left(\mathrm{H}_{2} \mathrm{O}\right)_{2}\right]$ & 19083 & ${ }^{2} B_{2 g} \rightarrow{ }^{2} B_{1 g}\left(v_{2}\right)$ & 1.86 \\
\hline & 24038 & ${ }^{2} \mathrm{E}_{\mathrm{g}} \rightarrow{ }^{2} \mathrm{~B}_{1 \mathrm{~g}}\left(\mathrm{v}_{3}\right)$ & \\
\hline & 12315 & ${ }^{3} \mathrm{~A}_{2 \mathrm{~g}} \rightarrow{ }^{3} \mathrm{~T}_{2 \mathrm{~g}}(\mathrm{~F})\left(\mathrm{v}_{1}\right)$ & \\
\hline$\left[\mathrm{Ni}(\mathrm{BEA}) \cdot\left(\mathrm{H}_{2} \mathrm{O}\right)_{2}\right]$ & 14450 & ${ }^{3} \mathrm{~A}_{2 \mathrm{~g}} \rightarrow{ }^{3} \mathrm{~T}_{1 \mathrm{~g}}(\mathrm{~F})\left(\mathrm{v}_{2}\right)$ & 3.01 \\
\hline & 20283 & ${ }^{3} \mathrm{~A}_{2 g} \rightarrow{ }^{3} \mathrm{~T}_{1 \mathrm{~g}}(\mathrm{P})\left(\mathrm{v}_{3}\right)$ & \\
\hline & 10869 & ${ }^{4} \mathrm{~T}_{1 \mathrm{~g}}(\mathrm{~F}) \rightarrow{ }^{4} \mathrm{~T}_{2 \mathrm{~g}}(\mathrm{~F})$ & \\
\hline$\left[\mathrm{Co}(\mathrm{BEA}) \cdot\left(\mathrm{H}_{2} \mathrm{O}\right)_{2}\right]$ & 16666 & ${ }^{4} \mathrm{~T}_{1 \mathrm{~g}}(\mathrm{~F}) \rightarrow{ }^{4} \mathrm{~A}_{2 \mathrm{~g}}(\mathrm{~F})$ & 4.40 \\
\hline & 19011 & ${ }^{4} \mathrm{~T}_{\mathrm{lg}}(\mathrm{F}) \rightarrow{ }^{4} \mathrm{~T}_{\mathrm{lg}}(\mathrm{P})$ & \\
\hline
\end{tabular}

Thermal studies: From the thermogram of [VO(BEA)] given in Fig. 2, it was observed that the compound is thermally stable upto $130{ }^{\circ} \mathrm{C}$ indicated by a well defined horizontal plateau. The first stage decomposition is seen starting at 130 ${ }^{\circ} \mathrm{C}$ and progressing till $290{ }^{\circ} \mathrm{C}$. The weight loss during this stage was $70 \%$. The second stage of decomposition starts at $290{ }^{\circ} \mathrm{C}$ itself and ends at $600{ }^{\circ} \mathrm{C}$ with mass loss of $12.5 \%$. Above $600{ }^{\circ} \mathrm{C}$ the residue is seen stable at static air atmosphere, with a mass percentage of $17.5 \%$. The compound was stable upto $130^{\circ} \mathrm{C}$, indicates that there is no water molecules attached to it. The first and second stage of decomposition was due to the breaking of bulky tetradentate Schiff bases from the complex, leaving behind a residue, $\mathrm{V}_{2} \mathrm{O}_{5}$, stable oxide of vanadium. The calculated value of the residue $17.63 \%$ is in good agreement with the observed value of $17.5 \%$.

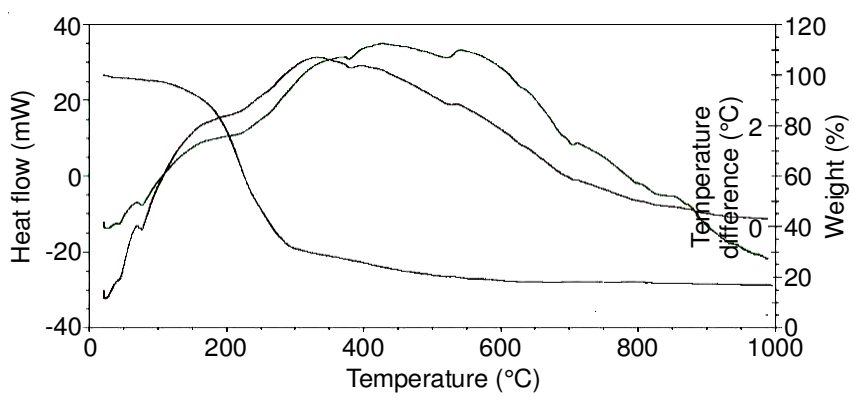

Fig. 2. TG/DTA curve of [VO(BEA)] in static air

\section{[VO(BEA) $] \stackrel{130-600^{\circ} \mathrm{C}}{\longrightarrow} 1 / 2 \mathrm{~V}_{2} \mathrm{O}_{5}+$ Gaseous products}

Thermal curve of $\mathrm{Ni}^{2+}$ complex $\left[\mathrm{Ni}(\mathrm{BEA})\left(\mathrm{H}_{2} \mathrm{O}\right)_{2}\right]$ in static air atmosphere is given in Fig. 3. It shows an initial mass loss of $6.5 \%$ in the range $50-100{ }^{\circ} \mathrm{C}$ itself, due to the loss of two water molecules from the complex. The calculated value of $6.62 \%$ is in good agreement with this. The second stage of decomposition starts at $100{ }^{\circ} \mathrm{C}$ and progressing till $363.56^{\circ} \mathrm{C}$ with a mass loss of $53.5 \%$ and third stage was in the range $363.56-650{ }^{\circ} \mathrm{C}$ with a mass loss of about $25.8 \%$ leaving behind a residual percentage of $14.2 \%$. Above $650{ }^{\circ} \mathrm{C}$ a horizontal plateau was observed. The second and third stage of decomposition corresponds to the decomposition of bulky ligand from the complex leaving $\mathrm{NiO}$, as the stable residue. The calculated value of the residue $13.75 \%$ is in good agreement with the observed value of $14.2 \%$.

$$
\begin{gathered}
\text { Stage I } \left.\left[\mathrm{Ni}(\mathrm{BEA})\left(\mathrm{H}_{2} \mathrm{O}\right)_{2}\right] \stackrel{\text { heating }}{\longrightarrow} \mathrm{Ni}(\mathrm{BEA})\right]+2 \mathrm{H}_{2} \mathrm{O} \\
\text { Stage II }[\mathrm{Ni}(\mathrm{BEA})] \longrightarrow \mathrm{NiO}+\text { gaseous products }
\end{gathered}
$$

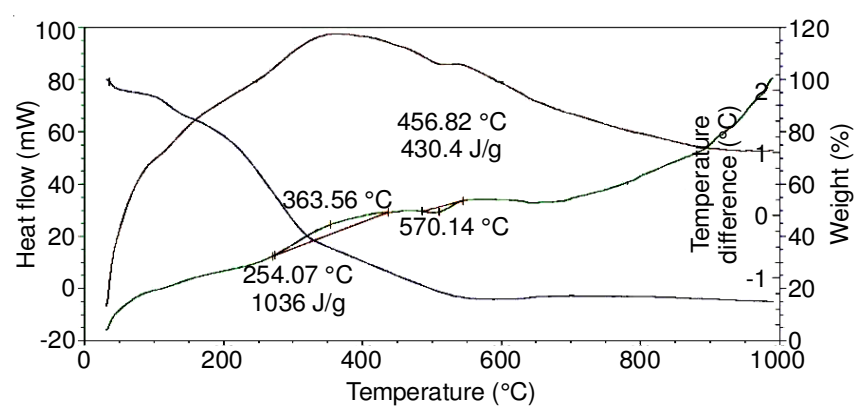

Fig. 3. TG/DTA curve of $\left[\mathrm{Ni}(\mathrm{BEA}) \cdot\left(\mathrm{H}_{2} \mathrm{O}\right)_{2}\right]$ in static air

ESR spectroscopy: The X-band ESR spectrum of the complex [VO(BEA)] was recorded in DMSO at LNT (77 K), given in Fig. 4. In the frozen state, it shows two sets of eight lines which are due to parallel and perpendicular resonance feature of $\mathrm{VO}^{2+}$. The eight line peaks are due to hyperfine splitting originating from the interaction of unpaired electrons with ${ }^{51} \mathrm{~V}$ nucleus having a nuclear spin of $I=7 / 2$. This confirms the presence of single oxovanadium(IV) in the complex [23,24]. The $\mathrm{g}_{\|}, \mathrm{g}_{\perp}, \mathrm{g}_{(\mathrm{av})}, \mathrm{A}_{\|}, \mathrm{A}_{\perp}$ and $\mathrm{A}_{(\mathrm{av})}$ are calculated using the equation:

$$
\begin{gathered}
\mathrm{g} \beta \mathrm{H}=\mathrm{h} \nu \\
\mathrm{g}_{(\mathrm{av})}=1 / 3\left(\mathrm{~g}_{\|}+2 \mathrm{~g}_{\perp}\right) \\
\mathrm{A}_{\text {(av) }}=1 / 3\left(\mathrm{~A}_{\|}+2 \mathrm{~A}_{\perp}\right)
\end{gathered}
$$

The observed values are $\mathrm{g}_{\|}=1.97, \mathrm{~g}_{\perp}=1.99, \mathrm{~g}_{\text {(av) }}=1.9833$; $\mathrm{A}_{\|}=194 \mathrm{G}, \mathrm{A}_{\perp}=74 \mathrm{G}, \mathrm{A}_{(\mathrm{av})}=114 \mathrm{G}$.

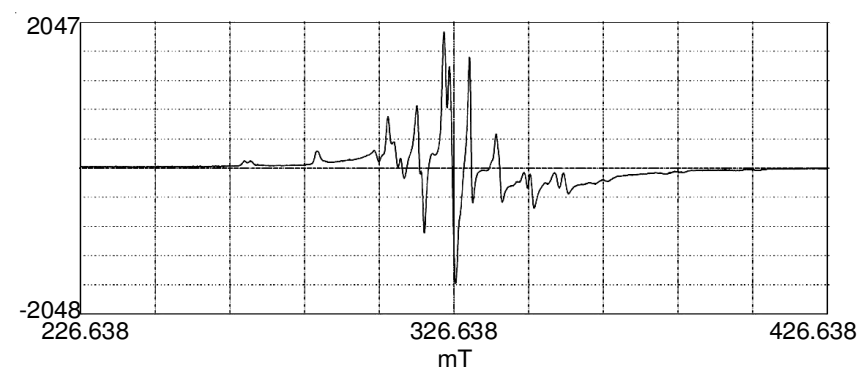

Fig. 4. ESR spectrum of [VO(BEA)] in LNT 
It was found that $g_{\|}<g_{\perp}$ in the complex which is in good agreement with its square pyramidal geometry.

The X-band ESR spectrum of $\left[\mathrm{Cu}(\mathrm{BEA}) \cdot\left(\mathrm{H}_{2} \mathrm{O}\right)_{2}\right]$ in DMSO in the frozen state at $77 \mathrm{~K}$ shows four well resolved peaks of low intensities in the low field region and one intense peak in the high field region given in Fig. 5. It was found that the $\mathrm{g}_{\|}$value is $2.3463, \mathrm{~g}_{\perp}=2.0645$ and $\mathrm{g}_{\text {(av) }}=1 / 3\left(\mathrm{~g}_{\|}+2 \mathrm{~g}_{\perp}\right)=$ 2.1524. The $g$ tensor values of copper(II) complex can be used to derive the ground state of the complex. If $g_{\|}>g_{\perp}>2.0023$, the unpaired electron lies in the $d_{x^{2}-y^{2}}$ orbital and $g_{\perp}>g_{\| 1}>$ 2.0023 , the unpaired electron is in the $\mathrm{d}_{\mathrm{z}^{2}}$ orbital. The interaction term $G$ is calculated using the equation $G=\left(g_{\| 1}-2.0023\right) /$ $\left(g_{\perp}-2.0023\right)$ and is greater than 4 . The local tetragonal axes are aligned parallel or only slightly misaligned, while $\mathrm{G}<$ 4.0, significant exchange coupling is present and the misalignment is appreciable. From the observed value it was clear that $\mathrm{g}_{\|}(2.3463)>\mathrm{g}_{\perp}(2.0645)>2.0023$ and the value of $\mathrm{G}$ in $\mathrm{a}$ complex 5.53 suggests that the local tetragonal axes are aligned parallel or slightly misaligned, the unpaired electron is present in $\mathrm{d}_{\mathrm{x}^{2}-\mathrm{y}^{2}}$ orbital [25-27] and the complex is distorted octahedral.

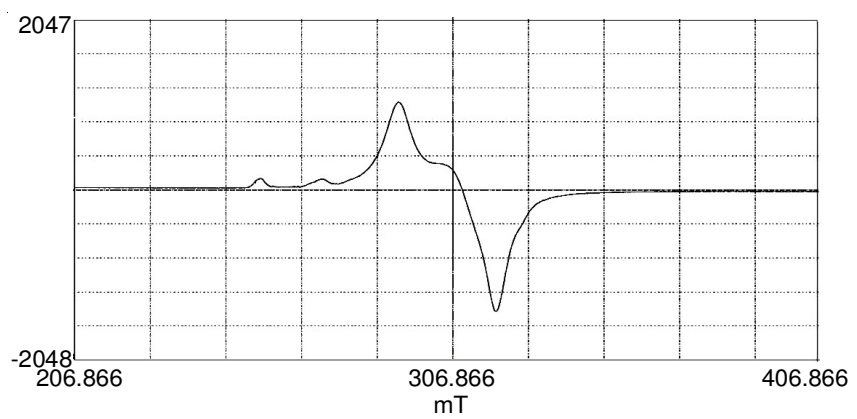

Fig. 5. ESR spectrum of $\left[\mathrm{Cu}(\mathrm{BEA}) \cdot\left(\mathrm{H}_{2} \mathrm{O}\right)_{2}\right]$ in LNT

Antibacterial studies: The ligand and its metal complexes were assayed for their antimicrobial activities against $E$. coli, $S$. aureus, $P$. aeruginosa, Serratia sp and Bacillus cereus by the disc diffusion method [28,29]. It was found that all the metal complexes have better activity than the ligands explained by the theory of Tweedy. This is probably due to the greater lipophilicity nature of the complexes. Such increased acivity of metal chelates can be explained on the basis of overtones concept and chelation theory. According to overtone's concept of cell permeability the lipid membrane that surrounds the cell favours the passage of lipid soluble materials. On chelation, the polarity of metal ion will be reduced to a greater extent due to overlap of the ligand orbitals and partial sharing of positive charge of the metal ion with donor groups. Therefore the delocalization of $\pi$ electrons in the chelate ring increases and enhances the penetration of the complexes into lipid membranes. The antibacterial data are presented in Table- 4 .

\section{Conclusion}

In this work, the synthesis and characterization of tetradentate Schiff base ligand derived from benzil and anthranilic acid and its interaction with various transition metals like $\mathrm{VO}^{2+}$, $\mathrm{Cu}^{2+}, \mathrm{Ni}^{2+}$ and $\mathrm{Co}^{2+}$ are reported. The metal complexes formed were non-electrolytic in nature. The synthesized systems were characterized by micro-analysis, molar conductance values, FTIR, ESR, UV spectroscopy and TG analyses. These analytical and spectral data suggests that azomethine $\mathrm{N}$ atoms, oxygens from carboxyl group are coordinated to oxovanadium(IV) resulted into $\mathrm{VO}\left(\mathrm{N}_{2} \mathrm{O}_{2}\right)$ square pyramidal structure and due to two molecules of coordinated water, octahedral geometry was predicted for the others. The antibacterial screening tests were also performed against bacteria which indicate that the complexes exhibit good antibacterial activity than the ligand. Based on the above results, the structure of coordination compounds under investigation are formulated in Fig. 6.

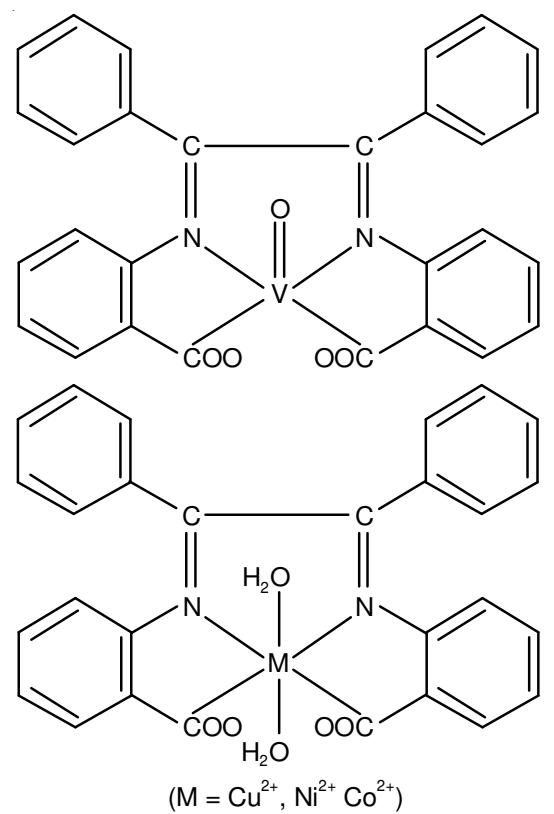

Fig. 6. Proposed structure of the metal complexes

\section{ACKNOWLEDGEMENTS}

The authors are thankful to The Principal, Govt. Arts College, Ooty; The Head, Department of Chemistry, Govt. Arts College, Ooty; The Head, Department of Pharmaceutical Chemistry, JSS College of Pharmacy, Ooty; The Head, SAIF, Pondicherry University; The Head, SAIF, CECRI,Karaikudi and The Head, SAIF, IIT-Chennai; The Head, Department of Chemistry, SRMV College of Arts \& Science, Coimbatore and Madurai Kamaraj University, Madurai, India for recording the spectral data and performing the antibacterial studies.

\begin{tabular}{lccccccc}
\multicolumn{7}{c}{ TABLE-4 } \\
& \multicolumn{2}{c}{ ANTIBACTERIAL ACTIVITY DATA OF THE LIGAND AND ITS METAL COMPLEXES } \\
\hline \multicolumn{1}{c}{ Compound } & Escherichia coli & $\begin{array}{c}\text { Staphylococcus } \\
\text { aureus }\end{array}$ & $\begin{array}{c}\text { Pseudomonas } \\
\text { aeruginosa }\end{array}$ & Serratia sp & Bacillus cereus & Inference \\
\hline $\mathrm{C}_{28} \mathrm{H}_{20} \mathrm{~N}_{2} \mathrm{O}_{4}(\mathrm{BEA})$ & 9 & 12 & 8 & 9 & 12 & 12 & ++ \\
{$[\mathrm{VO}(\mathrm{BEA})]$} & 15 & 14 & 12 & 8 & ++ & ++ \\
{$\left[\mathrm{Cu}(\mathrm{BEA}) \cdot\left(\mathrm{H}_{2} \mathrm{O}\right)_{2}\right]$} & 9 & 14 & 8 & 9 & 11 & ++ \\
{$\left[\mathrm{Ni}(\mathrm{BEA}) \cdot\left(\mathrm{H}_{2} \mathrm{O}\right)_{2}\right]$} & 10 & 16 & 6 & 10 & 9 & ++ \\
{$\left[\mathrm{Co}(\mathrm{BEA}) \cdot\left(\mathrm{H}_{2} \mathrm{O}\right)_{2}\right]$} & 9 & 15 & 8 & & ++ \\
\hline
\end{tabular}




\section{REFERENCES}

1. B. Kumar, B.K. Rai and N. Ambastha, Oriental J. Chem., 27, 1173 (2011)

2. H. Torayama, T. Nishide, H. Asada, M. Fujiwara and T. Matsushita, Polyhedron, 16, 3787 (1997);

https://doi.org/10.1016/S0277-5387(97)00148-4.

3. T. Punniyamurthy, S.J.S. Kalra and J. Iqbal, Tetrahedron Lett., 36, 8497 (1995);

https://doi.org/10.1016/0040-4039(95)01780-L.

4. G.S. Trivedi and N.C. Desai, Indian J. Chem., B31, 366 (1992)

5. S. Kumar. D.N. Dhar and P.N. Saxena, J. Sci. Ind. Res., 68, 181 (2009).

6. B.B. Mahapatra, B.K. Mahapatra and S. Guru, J. Inorg. Nucl. Chem., 39, 2291 (1977);

https://doi.org/10.1016/0022-1902(77)80419-3.

7. V.B. Rana, D.P. Singh, D.P. Singh and M.P. Teotia, Transition Met. Chem., 7, 174 (1982);

https://doi.org/10.1007/BF01035836.

8. S. Chandra and K.K. Sharma, Transition Met. Chem., 8, 1 (1983); https://doi.org/10.1007/BF00618784.

9. W.U. Malik, R. Bembi, R. Singh, S.P. Taneja and D. Raj, Inorg. Chim. Acta, 68, 223 (1983); https://doi.org/10.1016/S0020-1693(00)88965-3.

10. P. Bora and H.S. Yadav, Iranian J. Sci. Technol., 37A3, 310 (2013).

11. G.G. Mohamed, M.M.M. Omar and A.M.M. Hindy, Spectrochim. Acta Part A: Molecul. Biomol. Spectrosc., 62, 1140 (2005); https://doi.org/10.1016/j.saa.2005.03.031.

12. K.B. Gudasi, V.C. Havanur, S.A. Patil and B.R. Patil, Metal Based Drugs, Article ID 37348 (2007); https://doi.org/10.1155/2007/37348.

13. K. Nakomato, Infrared Spectra of Inorganic and Coordination Compounds, Wiley, New York, pp. 234-241 (1963).

14. K.S. Patel and M.O. Agwara, Nigerian J. Sci., 24, 107 (1990).
15. X.R. Bu, E.A. Mintz, X.Z. You, R.X. Wang, Y. Qi, Q.J. Meng, Y.J. Lu and D. Van Derveer, Polyhedron, 15, 4585 (1996); https://doi.org/10.1016/0277-5387(96)00220-3.

16. J.R. Zamian, E.R. Dockal, G. Castellano and G. Oliva, Polyhedron, 14, 2411 (1995); https://doi.org/10.1016/0277-5387(95)00071-Y.

17. A.B.P. Lever, Inorganic Electronic Spectroscopy, Elsevier, New York, edn 2 (1968)

18. L.N. Sharada and M.C. Ganorkar, Indian J. Chem., 27A, 617 (1988).

19. R.L. Dutta and A. Syamal, Elements of Magnetochemistry, East West Press, New Delhi, edn 2 (1992).

20. R.L. Farmer and F.L. Urbach, Inorg. Chem., 13, 587 (1974); https://doi.org/10.1021/ic50133a017.

21. B.N. Figgis, Introduction to Ligand Fields, Interscience, New York, p. 218 (1966)

22. M.S. Suresh and M. Padmanabhan, Asian J. Chem., 25, 769 (2013); https://doi.org/10.14233/ajchem.2013.14564.

23. A.L. Sharma, I.O. Singh, M.A. Singh, H.R. Singh, R.M. Kadam, M.K. Bhide and M.D. Sastry, Transition Met. Chem, 26, 532 (2001); https://doi.org/10.1023/A:1011063631998.

24. T.F. Yen, Electron Spin Resonance of Metal Complexes, Plenum Press, New York, edn 1 (1969).

25. B.J. Hathaway and D.E. Billing, Coord. Chem. Rev., 5, 143 (1970); https://doi.org/10.1016/S0010-8545(00)80135-6.

26. I.M. Procler, B.J. Hathaway and P. Nicholls, J. Chem. Soc. A, 1678 (1986); https://doi.org/10.1039/J19680001678.

27. M.S. Suresh and V. Prakash, Int. J. Phys. Sci., 5, 1443 (2010).

28. N. Raman, S. Ravichandran and C. Thangaraja, Indian Acad. Sci. J. Chem. Sci., 116, 214 (2004).

29. Z. Shirin and R.M. Mukherjee, Polyhedron, 11, 2625 (1992); https://doi.org/10.1016/S0277-5387(00)80232-6. 